\title{
South Africa should be using all the COVID-19 vaccines available to it - urgently
}

The health and economic effects of SARS-CoV-2 have been devastating to South Africa (SA). At the time of writing, the country is ill-prepared for mitigating a third wave, with only a minority of largely urban health workers being vaccinated against COVID-19 and roll-out to the general population yet to start. This despite SA being the first country on the continent to receive vaccines - 1 million AstraZeneca SARS-CoV-2 (AZ) vaccine doses on 1 February 2021.

We note with dismay the reselling of the AZ vaccines to the African Union $^{[1]}$ despite the B.1.351 variant, the dominant variant during SA's second wave, circulating in much of Africa. We believe that SA has squandered the opportunity to protect at least half a million of its most vulnerable citizens before the next resurgence, with massive healthcare and economic cost. Alternatives to the AZ vaccine will not be available to South Africans within the next few months to make up the shortfall.

Why has there been a refusal in the National Department of Health $(\mathrm{NDoH})$ and the Ministerial Advisory Committee on Vaccines (MAC-Vac) to use the AZ vaccine locally? The continued insistence by the NDoH and the MAC-Vac on not using it is out of step with recommendations by the World Health Organization (WHO) and other normative agencies, and the current state of vaccine science. ${ }^{[2,3]}$ Unfortunately, none of the MAC-Vac's advisories, rationales or decisions have been published in the public domain since 3 January 2021, and none of the debate around specific vaccine choices has therefore been open to the public or the broader scientific community. From media interviews, the chief reason appears to be concern about the lower efficacy against the B.1.351 variant. This followed findings from a study conducted in SA that failed to demonstrate efficacy of $>60 \%$ (the hypothesis being tested and for which the study was powered to address) against infection with COVID-19, after two vaccine doses. ${ }^{[4]}$ The study demonstrated a $75 \%$ reduced risk of mild to moderate COVID-19 caused by the first-wave ancestry virus 14 days after the first dose, but with no significant protection against mild to moderate disease caused by the B.1.351 variant after two doses of the vaccine. There were no severe COVID-19 cases in either the vaccine or the placebo arm, as the participants were young and largely healthy; this study was not suited to assess whether the AZ vaccine protects against severe disease, which is largely seen in older patients and those with serious comorbidities, whether caused by B.1.351 or any other variant. Animal challenge studies following AZ vaccination have reported 9-fold reduction in neutralising antibody activity against the B.1.351 variant relative to ancestry virus, similar to that observed for natural induced antibody following infection by prototype-like virus infection. ${ }^{[5]}$ However, immunised animals were fully protected against severe lower respiratory tract infection following challenge by the variants. ${ }^{[6]}$

SA's muddled procurement strategy is further demonstrated by the commitment to buy 20 million doses of the Pfizer vaccine, for which there is no clinical evidence of efficacy against the B.1.351 variant. We agree with the decision to purchase the Pfizer vaccine, but the NDoH must concede that it then makes a mockery of the argument that we cannot use the AZ vaccine because of a lack of data against severe disease caused by this same B.1.351 variant. The Pfizer vaccine, like most other first-generation COVID-19 vaccines, is likely to confer high levels of protection against severe COVID-19, even caused by the B.1.351 variant. Nevertheless, laboratory testing has demonstrated 3 -fold or more reduction of the vaccine-induced neutralising antibody against the B.1.1351 variant relative to activity against the ancestry virus, suggesting that there would be diminished protection against mild COVID-19 caused by the B.1.1351 variant. Intriguingly, SA has not included the Novavax vaccine as part of its roll-out strategy, despite this being the only COVID-19 vaccine to report on efficacy (49-60\%) against mild to moderate COVID-19 caused by the B.1.351 variant, and $100 \%$ protection against severe COVID-19. ${ }^{[7]}$ The only other COVID-19 vaccine that SA has now committed to purchasing is the Johnson \& Johnson (J\&J) vaccine, for which efficacy against severe COVID-19 caused by the B.1.1351 variant is $82 \%$, while efficacy against mild illness caused by the B.1.351 variant is yet to be reported on. The Moderna, Sputnik V and Sinopharm vaccines, with no public commitment to procure by the $\mathrm{NDoH}$, have similarly not had B.1.351 data reported.

To summarise the evidence, the AZ vaccine is extremely safe and provides near-total protection against severe COVID-19 caused by ancestry virus, much like other vaccines such as the J\&J, Pfizer, Moderna, Novavax and Sputnik- $V^{[8,9]}$ There are no published data on the Sinopharm vaccine, which is also widely used. Prior natural infection with SARS-CoV-2 is similarly highly protective against severe COVID-19, ${ }^{[10,11]}$ while it may not protect against mild infection by the B.1.351 variant ${ }^{[7]}$ (Fig. 1 and Table 1). Taken together, the data suggest that COVID-19 vaccines (or prior infection) may not provide sterilising immunity or protect against mild COVID-19 caused by the B.1.351 variant, because of the relative resistance of this variant to antibody-neutralising activity. Nevertheless, the current first-generation spike-protein-based COVID-19 vaccines are likely to still confer substantial protection against severe disease, ${ }^{[13]}$ because vaccine-induced CD8 (natural killer) cell responses are largely unaffected by mutations observed in the B.1.351 spike protein. It will be impossible to fully assess the impact of each COVID-19 vaccine against the B.1.351 variant and other similar variants that continue evolving, so we are reliant on a combination of immunogenicity studies, clinical trials, animal model challenge studies and observational data from mass vaccination programmes. ${ }^{[14]}$ All data points suggest that the current first-generation COVID-19 vaccines induce sufficient immunity to substantially reduce the risk of severe COVID-19, and no data suggest the contrary. Misguided comparisons of different endpoints from different studies, evaluated in different population demographics, done in different countries and at different times, have been used as evidence that the $A Z$ vaccine may be inferior to other vaccines. Although the $\mathrm{AZ}$ vaccine does not reduce the risk of mild COVID-19 caused by the B.1.351 variant, even if the protection against severe disease and death afforded by the $\mathrm{AZ}$ vaccine ends up being just half or a third of what it is with comparator vaccines (a highly unlikely scenario), it is irresponsible to pass up the opportunity to reduce the number of deaths in the absence of alternative vaccines.

Where the $\mathrm{AZ}$ vaccine is in use, mortality in vaccinated populations has plummeted, including in the UK, home to its own more infectious and virulent B.1.1.7 variant. ${ }^{[15]}$ The fact that 'breakthrough' infections by variants, causing hospitalisation and death, have not been reported in tens of millions of Europeans given the AZ vaccine, is highly reassuring.

Cost or a desire 'not to waste money' has been cited as a reason for delaying use and reselling of the AZ vaccine, an argument comprehensively disputed when matched against the cost of infection 


\begin{tabular}{|c|c|c|c|c|c|c|c|}
\hline Company & Platform & 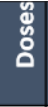 & Non-clinical results & $\begin{array}{l}\text { \# with } \\
\text { vaccine (same } \\
\text { placebo) }\end{array}$ & $\begin{array}{l}\text { Protection } \\
\text { from COVID-19 } \\
\text { hospitalization }\end{array}$ & $\begin{array}{l}\text { Protection from } \\
\text { covid severe } d z \\
\text { (some at home) }\end{array}$ & $\begin{array}{l}\text { Efficacy against } \\
\text { milder COVID }\end{array}$ \\
\hline moderna & $\begin{array}{l}\text { mRNA-1273 } \\
\text { mRNA in lipid } \\
\text { nanoparticle }\end{array}$ & 2 & $\begin{array}{l}\text { Neutralizing Abs; Strong } \\
\text { Th1 CD4+ protection } \\
\text { from challenge } \\
\text { (macaques) }\end{array}$ & $\sim 15,000$ & $\begin{array}{l}97 \% \text { ( } 1 \text { in } \\
\text { vaccine arm } \\
\text { after } 2 \text { nd dose } \\
\text { hospitalized) }\end{array}$ & $\begin{array}{l}97 \% \text { ( } 30 \text { cases in } \\
\text { placebo arm; } 0 \text { in } \\
\text { vaccine reported but } \\
1 \text { severe per FDA) }\end{array}$ & $94.1 \%$ \\
\hline Pfrer & $\begin{array}{l}\text { BNT162b2 } \\
\text { mRNA in lipid } \\
\text { nanoparticle }\end{array}$ & 2 & $\begin{array}{l}\text { Neutralizing Abs; Strong } \\
\text { Th1 CD4+, CD8+; } \\
\text { protection from } \\
\text { challenge (macaques) }\end{array}$ & $\sim 18,600$ & $100 \%$ & $\begin{array}{l}100 \% \text { ( } 9 \text { cases in } \\
\text { placebo arm; } 0 \text { in } \\
\text { vaccine- } 1 \text { initially } \\
\text { severe but not) }\end{array}$ & $95 \%$ \\
\hline gohmonafolmon & $\begin{array}{l}\text { JNJ-78436725 } \\
\text { Non-replicating } \\
\text { human } \\
\text { adenovirus/DNA }\end{array}$ & 1 & $\begin{array}{l}\text { Neutralizing Abs; Strong } \\
\text { Th1 CD4+ > Th2; CD8+; } \\
\text { challenge protection } \\
\text { (macaque) }\end{array}$ & $\begin{array}{l}\sim 22,000 \text { US, } \\
\text { Latin America, } \\
\text { S. Africa }\end{array}$ & $100 \%$ & $\begin{array}{l}85.4 \% \text { across } 3 \text { sites } \\
\text { ( } 7 \text { deaths, } 16 \\
\text { hospitalizations, all in } \\
\text { placebo arm) }\end{array}$ & $\begin{array}{l}72 \% \text { US; } 61 \% \\
\text { Latin America; } \\
64 \% \text { S. Africa } \\
(95 \% \text { B1.351) }\end{array}$ \\
\hline AstraZeneca & $\begin{array}{l}\text { AZD } 1222 \\
\text { Non-replicating } \\
\text { Chimp Adenovirus- } \\
\text { DNA }\end{array}$ & 2 & $\begin{array}{l}\text { Neutralizing Abs; Strong } \\
\text { Th1 CD4+ > Th2; CD8+; } \\
\text { protection from } \\
\text { challenge (macaques) }\end{array}$ & $\begin{array}{l}\sim 24813 \text { (UK, } \\
\text { SA, US/Peru/ } \\
\text { Chili) }\end{array}$ & $100 \%$ & $\begin{array}{l}100 \% \text { (UK, } 15 \text { placebo } \\
\text { arm hospitalized, } 0 \text { in } \\
\text { vaccine; US, } 5 \text { severe } \\
\text { in placebo, } 0 \text { vaccine) }\end{array}$ & $\begin{array}{l}79 \% \text { overall US; } \\
70 \% \text { UK; S. } \\
\text { Africa trial } \\
\text { halted for mild }\end{array}$ \\
\hline NOVAVAX & $\begin{array}{l}\text { NVX-CoV2373 } \\
\text { Spike protein/RBD + } \\
\text { Matrix M adjuvant }\end{array}$ & 2 & $\begin{array}{l}\text { Neutralizing Abs; Strong } \\
\text { Th1 CD4 > Th2; } \\
\text { challenge protection } \\
\text { (macaques) }\end{array}$ & $\begin{array}{l}\sim 8833 \text { (Phase } \\
3 \text { UK; 2b SA) }\end{array}$ & $100 \%$ & $\begin{array}{l}100 \% \text { ( } 10 \text { severe in } \\
\text { placebo in UK/SA; } 0 \\
\text { in vaccine) }\end{array}$ & $\begin{array}{l}96.4 \% \text { UK; } 89 \% \\
\text { B117 UK; 55\% } \\
\text { SA (94\% B1351) }\end{array}$ \\
\hline S:putnik V & $\begin{array}{l}\text { Ad26 and Ad5 } \\
\text { adenovirus/DNA }\end{array}$ & 2 & $\begin{array}{l}\text { NAbs; IFN- } \gamma \text { secretion } \\
\text { PMBCs, cellular }\end{array}$ & $\sim 14964$ & $100 \%$ & $\begin{array}{l}100 \% \text { ( } 20 \text { in placebo; } \\
0 \text { vaccine) }\end{array}$ & $91.6 \%$ \\
\hline
\end{tabular}

Fig. 1. Description of six SARS-Cov-2 vaccine clinical studies (adapted from figure provided by Dr Monica Gandhi, ${ }^{[12]}$ used with permission).

Table 1. Description of six SARS-Cov-2 vaccines against variants

\begin{tabular}{llll}
\hline & $\begin{array}{l}\text { Reduction of neutralising activity } \\
\text { in laboratory assays }\end{array}$ & $\begin{array}{l}\text { Clinical efficacy against the } \\
\text { B.1.351 variant }\end{array}$ & $\begin{array}{l}\text { Clinical efficacy against } \\
\text { ancestral variant }\end{array}$ \\
\hline Pfizer & $3-42 \times$ & Unknown & $95 \%$ \\
Moderna & $6-28 \times$ & Unknown & $94.1 \%$ \\
AstraZeneca & $3.5-21 \times /$ undetectable & $10 \%$ (mild to moderate) & $70.4 \%$ \\
Gamaleya (Sputnik-V) & Unknown & Unknown & $91.6 \%$ \\
Johnson \& Johnson & Pending & $64 \%$ (moderate to severe) & $72 \%$ (moderate to severe disease) \\
& & $82 \%$ (severe) & \\
Novavax & Pending & $49 \%$ (including HIV; mild to & $89 \%$ \\
& & moderate) & \\
& & $60 \%$ (excluding HIV; mild to & \\
& & moderate) & \\
Sinopharm & $100 \%$ (severe) & $79-86 \%$ \\
Sinovac & Unknown & $50.4 \%$ \\
& Unknown & &
\end{tabular}

and lockdowns on the economy. ${ }^{[16-18]}$ SA lost $~ 8.2 \%$ (ZAR389 billion) of its gross domestic product in 2020 as a result of the COVID19 pandemic. The cost (depending on which vaccine we use) of vaccinating everyone who needs it, is between ZAR8.6 and ZAR16.4 billion. ${ }^{[18]}$

Finally, sending the AZ vaccine to other African countries raises deep ethical concerns. The B.1.351 variant has been detected throughout Africa and may be responsible for the devastating second wave many countries have just experienced. ${ }^{[19,20]}$ If the SA authorities truly believed that the AZ vaccine did not work, why was it sold on to the African Union, and why would they purchase it?

Arguments about undermining vaccine confidence by not rolling out the perfect vaccine are misguided in terms of public health. SARS-CoV-2 spreads quickly, with unpredictable waves but predictable consequences. Speed of the vaccination programme is far more important than getting the perfect vaccine. The 'abundance of caution' argument ventured by members of the SA government, the
MAC-Vac and European governments, when dealing with efficacy and recent reported thrombotic side-effects of the $\mathrm{AZ}$ vaccine, has already seen the vaccine labelled 'second best', with reports of AZ-specific vaccine hesitance from around the globe. To be clear: the $\mathrm{AZ}$ vaccine is safe, and based on all known information, will be sufficiently effective in stopping the endpoints we care about most hospitalisation and death.

We understand that a decision like this is complex, but as the reasoning behind it has not been made public, we are at a loss to explain the government's action. Politicians and advisory boards need to be transparent and explain decisions, and, if necessary, reverse them. If the $\mathrm{NDoH}$, the MAC-Vac or the regulator have access to new information, this needs to be made public. Transparency is critical to trust in public health. Currently, SA has misapplied standards hampering the rollout of a vital and available tool to mitigate the epidemic. Moreover, it has gone against guidance from the WHO. ${ }^{[2]}$ We do not have the luxury of choice or time. All the vaccines provide 
better protection against severe disease than against mild disease. The AZ vaccine should be regarded as sufficient to prevent at least a substantial proportion of the most severe health outcomes of SARSCoV-2 infection until data are produced to the contrary. Rapidly rolling out COVID-19 vaccine to our population at risk of severe disease and death is the most important strategic intervention to save lives, livelihoods and SA's health system and reducing the devastating effects of a third wave of COVID-19.

Declarations of interest. WDFV: Participant on the SA AZ COVID-19 vaccine trial. SAM: National principal investigator of the SA AZ COVID-19 vaccine trial (funded by the Bill and Melinda Gates Foundation (BMGF) and the South African Medical Research Council), and the Novavax COVID-19 vaccine trial (funded by Novavax and BMGF); all funding goes to institution (Wits Health Consortium).

\section{W D Francois Venter}

Ezintsha, Faculty of Health Sciences, University of the Witwatersrand, Johannesburg, South Africa

fventer@ezintsha.org

\section{Shabir A Madhi}

South African Medical Research Council Vaccines and Infectious Diseases Analytics Research Unit, Faculty of Health Sciences, University of the Witwatersrand, Johannesburg, South Africa

\section{Jeremy $\mathrm{Nel}$}

Head of Division of Infectious Diseases, Faculty of Health Sciences, University of the Witwatersrand, Johannesburg, South Africa

\section{Marc Mendelson}

Division of Infectious Diseases and HIV Medicine, Faculty of Health Sciences, University of Cape Town, South Africa

\section{Alex van den Heever}

Adjunct Professor and Chair, Social Security Systems Administration and Management Studies, Wits School of Governance, University of the Witwatersrand, Johannesburg, South Africa

\section{Mosa Moshabela}

Chief Medical Specialist and Dean in the School of Nursing and Public Health, University of KwaZulu-Natal, Durban, South Africa
1. Mkize DZ. Media Statement: The Minister of Health, Dr Zweli Mkhize, is pleased to announce that the sale of the Astra Zeneca vaccines that we had acquired has been concluded. Twitter, 21 March 2021 sale of the Astra Zeneca vaccines that we had acquired has been concluded. Twitter, 21 Marh
https://twitter.com/DrZweliMkhize/status/1373647784625238023 (accessed 24 March 2021).

2. World Health Organization. WHO lists two additional COVID-19 vaccines for emergency use and . World Health Organization. WHO lists two additional COVID-19 vaccines for emergency use and
COVAX roll-out. Press release, 15 February 2021. https://www.who.int/news/item/15-02-2021-whoCOVAX roll-out. Press release, 15 February 2021 . https: $/ /$ www.who.int/news/item/15-02-2021-who-
lists-two-additional-covid-19-vaccines-for-emergency-use-and-covax-roll-out (accessed 24 March lists-two-additional-covid-19-vaccines-for-emergency-use-and-covax-roll-out (accessed 24 March
2021). 3. Bateman C. Local experts at odds on whether the AstraZeneca vaccine should be used in South Africa
Daily Maverick, 17 March 2021. https://www.dailymaverick.co.za/article/2021-03-17-local-expertsDaily Maverick, 17 March 2021. https://www.dailymaverick.co.za/article/2021-03-17-local-experts-
at-odds-on-whether-the-astrazeneca-vaccine-should-be-used-in-south-africa/ (accessed 24 March 2021)

4. Madhi SA, Baillie V, Cutland CL, et al. Efficacy of the ChAdOx1 nCoV-19 Covid-19 vaccine against the B.1.351 Variant. N Engl J Med 2021 (epub 16 March 2021). https://doi.org/10.1056/NEJMoa2102214 5. Fischer RJ, van Doremalen N, Adney DR, et al. ChAdOx1 nCoV-19 (AZD1222) protects hamsters against SARS-CoV-2 B.1.351 and B.1.1.7 disease. bioRxiv 2020 (epub 15 March 2020). https://doi. org/10.1101/2021.03.11.435000

6. Van Doremalen $\mathrm{N}$, Lambe $\mathrm{T}$, Spencer $\mathrm{A}$, et al. ChAdOx1 $\mathrm{nCoV}-19$ vaccination prevents SARS-CoV-2 pneumonia in rhesus macaques. bioRxiv 2020 (epub 13 May 2020). https://doi. SARS-CoV-2 pneumonia in

7. Novavax. Novavax announces initiation of PREVENT-19 pivotal phase 3 efficacy trial of COVID-19 vaccine in the United States and Mexico. Press release, 28 December 2020. https://ir.novavax.com/
vavali vaccine in the United States and Mexico. Press release, 28 December 2020 . https://ir.novavax.com/
news-releases/news-release-details/novavax-announces-initiation-prevent-19-pivotal-phase-3efficacy (accessed 25 March 2021)

8. Voysey M, Clemens SAC, Madhi SA, et al. Safety and efficacy of the ChAdOx1 nCoV-19 vaccine (AZD1222) against SARS-CoV-2: An interim analysis of four randomised controlled trials in Brazil, South Africa, and the UK. Lancet 2021;397(10269):99-111. https://doi.org/10.1016/S01406736(20)32661-1

9. World Health Organization. Draft landscape and tracker of COVID-19 candidate vaccines. 23 March 2021. https://www.who.int/publications/m/item/draft-landscape-of-covid-19-candidate-vaccines (accessed 24 March 2021)

10. Hansen CH, Michlmayr D, Gubbels SM, Molbak K, Ethelberg S. Assessment of protection against reinfection with SARS-CoV-2 among 4 million PCR-tested individuals in Denmark in 2020: A population-level observational study. Lancet 2021 (epub 17 March 2021). https://doi.org/10.1016/ population-level observa

11. Lumley SF, O'Donnell D, Stoesser NE, et al. Antibody status and incidence of SARS-CoV-2 infection in health care workers. N Engl J Med 2021;384(6):533-540. https://doi.org/10.1056/NEJMoa2034545
ing 2 in health care workers. N Engl J Med 2021;384(6):533-540. https://doi.org/10.1056/NEJMoa2034545
2. Gandhi M. New table with results from AZ US trial released this am Have written Bharat (Covaxin), Sinopharm, Sinovac to get more details beyond press release, no answer to date (although they are al likely good; Covaxin also codes for spike protein; other 2 inactivated whole virus). Twitter, 22 March 2021. https://twitter.com/MonicaGandhi9/status/1374018648365432833 (accessed 24 March 2021).

13. Rubin R. COVID-19 vaccines vs variants - determining how much immunity is enough. JAMA 202 (epub 17 March 2021). https://doi.org/10.1001/jama.2021.3370

4. Klasse PJ, Nixon DF, Moore JP. Immunogenicity of clinically relevant SARS-CoV-2 vaccines in nonhuman primates and humans. Sci Adv 2021;7(12):eabe8065. https://doi.org/10.1126/sciadv. abe8065

5. Gov.UK. UK Coronavirus Dashboard. 2021. https://coronavirus.data.gov.uk/ (accessed 24 March 2021).

16. Molyneaux A. 'We will not waste the money': Mkhize updates SA on 'ineffective' AstraZeneca vaccine. TimesLive, 10 February 2021. https://www.timeslive.co.za/politics/2021-02-10-watch--we-will-notTimesLive, 10 February 2021. https://www.timeslive.co.za/politics/2021-02-10-watch--we-will-not-

17. Corbyn Z. Salim Abdool Karim: 'None of us are safe from Covid if one of us is not. We have mutual interdependence'. Guardian, 10 January 2021. https://www.theguardian.com/world/2021/
jan/10/salim-abdool-karim-none-of-us-are-safe-from-covid-if-one-of-us-is-not-we-have-mutualinterdependence (accessed 24 March 2021)

18. Van den Heever A, Valodia I, Lucy A, Veller M, Madhi S, Venter F. Towards herd immunity from Covid-19: Costing a vaccine strategy for South Africa. Daily Maverick, 7 January 2021. https://www dailymaverick.co.za/article/2021-01-07-towards-herd-immunity-from-covid-19-costing-a-vaccinestrategy-for-south-africa/ (accessed 24 March 2021).

19. Mwenda M, Saasa N, Sinyange N, et al. Detection of B.1.351 SARS-CoV-2 variant strain - Zambia, December 2020. MMWR Morb Mortal Wkly Rep 2021;70(8):280-282. https://doi.org/10.15585/ mmwr.mm7008e2

20. Pango. Pango lineages: A dynamic nomenclature proposal for SARS-CoV-2 lineages to assist genomi epidemiology. 2021. https://cov-lineages.org/global_report_B.1.351.html (accessed 24 March 2021).

S Afr Med J. Published online 25 March 2021. https://doi.org/10.7196/SAMJ.2021. v111i5.15716 